\title{
Marketing of Guava in Districts of Haryana State
}

\author{
Veer Sain, V. P. Luhach, Mohinder Singh Mehla and *ved jyoti \\ Research Schloar, Senior Scientist and *Research scholar( ICG IIS Univ.) \\ Deptt. of Agriculture Economics, CCS, Haryana Agricultural University, Hisar-125004 (Haryana)
}

\section{Introduction}

In Haryana, Guava is cultivated in few districts only. It ranks fifth in cultivation after citrus, mango, apple and pear. Guava is highly perishable fruit and should be marketed immediately after harvest. Under the existing marketing systems most of the fruit is marketed through a long chain of intermediaries thus price spread is quite evident. Guava fruit are used making jam, jellies and various culinary purposes. But due to poor infrastructure facility, poor handling and lack of cold storage facilities it is spoilt.

Guava fruit is commercially grown throughout the country. In India, production of guava is 2.27 Metric Tons with an area coverage of 0.20 million hectares (Kumar et al., 2010). In Haryana, production of guava is 0.053 Metric Tons with an area coverage of 0.007 million hectares (Anonymous, 2010).

The marketing cost per quintal of guava for group II (producer - retailer - consumer) was worked out to Rs. 92 and group III (producer - consumer) was Rs. 110.94. In marketing was done by channel II (producer retailer - consumer) Naphade and Tingre (2008).

Hence study on the marketing channel, margins and price spread aspects may provide some guidelines about the economics of guava. In this context, the study was undertaken with the following specific objectives:

1. To study the marketing channel of guava orchard in different district of Haryana

2. To work out the marketing margins from guava orchard in different district of Haryana

3. To work out the marketing price spread of guava orchard in different district of Haryana

4. To study the marketing efficiency of guava orchard in different district of Haryana

\section{Methodology}

The present study was conducted in Hisar district, Hansi, Barwala Block, and Fatehabad district Bhuna, Fatehabad Block and Sirsa district Baraguda, Sirsa Block of Haryana, which was selected purposively on basis of highest area and production under Guava cultivation. Further, Hisar, Fatehabad and Sirsa market were selected for the market study during 2011-2012. Finally 60 growers from randomly selected two blocks from each district were selected for the present study. On the basis of the nature of the data, budgeting technique and various economic tools were used for estimation of marketing channel, margins and price spread.

Evaluation of marketing system The different market functionaries such as contractors, commission agents, retailers and consumers were randomly selected from the market in the area under study. The data collected from the different market functionaries were analyzed to estimate the marketing costs and margins through important marketing channels.

\section{Selection of intermediaries}

The market channels of guava were examined by selecting a random sample of such intermediaries as pre harvest contractors, wholesalers, commission agents and the retailers. As the large number of guava farmer sell out their produce before maturity to per harvest contractors. So five commission agent/wholesalers six preharvest contractor and ten retailers were selected randomly from market to the study the marketing channels.

\section{Marketing pattern of guava}

Information regarding the marketing pattern/ channels of guava was collected from the producers and marketing agencies involved in the marketing of guava through different channel. Information was also obtained from the market intermediaries involved in the purchase of guava with in the village and in the market.

\section{Marketing margins and costs}

To find out the marketing margins and costs for different channels six commission agent / wholesalers, six pre-harvest contractor and twelve retailers were selected from the market. The relevant data were collected with the help of a pre tested, well designed schedule. Information regarding marketing aspects of guava was collected from the producers and the retailers in order to find out the producer's share in the price paid by the consumers. The main channels in operation in the marketing of guava were studied to work out the price spread. To estimate the marketing costs and margins through important marketing channels was used for computing the 
marketing margins. From the gross margins, the costs incurred by the concerned agencies were deducted to arrive at the net margins. The marketing efficiency of different marketing channels were worked out by using the following method.

(a) Shepherd's Method (ME), (Acharya and Agarwal 2011)

$$
\mathrm{RP} \div \mathrm{MC}
$$

Where

$\mathrm{RP}=$ Retailer's sale price or consumer's purchase price

$\mathrm{MC}=$ Total marketing costs

(b) Acharya's Method (MME), (Acharya and Agarwal 2011)

$$
\mathrm{FP} \div(\mathrm{MC}+\mathrm{MM})
$$

Where

$\mathrm{FP}=$ Net price received by farmer

$\mathrm{MC}=$ Total marketing costs

$\mathrm{MM}=$ Total net margins of intermediaries

(c) Conventional method, (Acharya and Agarwal 2011)

$\mathrm{E}=0 / \mathrm{I} \times 100$

Where

$\mathrm{O}=$ output is the value added

$\mathrm{I}=$ input is the real cost of marketing

$\mathrm{E}=$ marketing efficiency

\section{Marketing of guava}

\section{Results And Discusion}

Table-1, 2, 3, 4 and 5 showed that the marketing cost and margins were worked out for all the five marketing channels at Hisar, Fatehabad and Sirsa market. Comparing the results obtained through different channels, it was observed that the producer's share in consumer's rupee increased with the decrease of market functionaries. In the channel I and II net overall average share of producers were found to be 22.30 and 24.18 per cent of consumer's rupee. The producer's share in the consumer's rupee under overall average Channel III and IV were found to be 33.06 per cent and 38.73 per cent in the market. The highest net overall average price received by producer and share in consumer's rupee was found to be 94.31 per cent in channel V (Producer to direct consumer) in the study area. The share of producer in consumer's rupee was higher in Fatehabad district (95.61 per cent) in channel as compared to Hisar district was minimum in channel V (94.44 per cent) which was due to presence of better management and high yield in Fatehabad district. Due to this no pre-harvest contractor, commission agent, wholesaler and retailer. Also the price received by producer was maximum in Fatehabad and minimum in Hisar district. This channel was more appropriate because farmers get more benefit as compared to other channels. Similar findings were also reported by Sundaravaradarajan and Jaganmohan (2002), Randev (2005), Nirgude et al. (2007) and Abassian et al. (2012).

\section{Marketing efficiency}

The Table 6 depicted the marketing efficiency of guava in Hisar, Fatehabad, Sirsa market and overall average under different marketing channels. The marketing efficiency according to Acharya's method (Modified Measure of Marketing Efficiency) under different marketing channels i.e. Channel I, Channel II, Channel III, Channel IV and Channel V were $0.28,0.31,0.49,0.60$ and 16.57 in overall average respectively. From this efficiency index it could be observed that channel $\mathrm{V}$ was the most efficient among all marketing channels. This was because of the fact that in Channel V intermediaries were not involved and hence this channel was most efficient than all other channels. Moreover, marketing efficiency increased with the decrease in market intermediaries between producer and consumer. The marketing efficiency according to Conventional method under different marketing channels i.e. Channel I, Channel II, Channel III, Channel IV and Channel V were 4.16, 4.78, 3.45, 4.00 and 1.00 in Overall average respectively. From this efficiency index it could be observed that Channel $\mathrm{V}$ was the most efficiency among all marketing channels. The marketing efficient according to Sephard's method under different marketing channels i.e. Channel I, Channel II, Channel III, Channel IV and Channel V were 5. 5.36, 6.30, 5.15, 1.60, 17.57 in Overall average, respectively. From this efficiency index it could be observed that channel V was the most efficient among all marketing channels. Similar findings were also reported by Malaisamy et al. (2007) 
Table 1: Price spread of guava in marketing channel-I in Hisar, Fatehabad, Sirsa markets and Overall average

\begin{tabular}{|c|c|c|c|c|c|}
\hline $\begin{array}{l}\mathbf{S} \\
\mathbf{r}\end{array}$ & Particulars & Hisar & Fatehabad & Sirsa & $\begin{array}{c}\text { Overall } \\
\text { average }\end{array}$ \\
\hline 1 & $\begin{array}{l}\text { Net Price received by producer/purchase Price of pre- } \\
\text { harvest contractor }\end{array}$ & $810(23.14)$ & $820(21.58)$ & $800(21.05)$ & $810(22.30)$ \\
\hline 2 & Cost incurred by the pre-harvest contractor & & & & \\
\hline & i. Watch and ward & $34.72(0.99)$ & $36.86(0.97)$ & $35.44(0.93)$ & $35.67(0.98)$ \\
\hline & ii.Picking, grading and packing cost & $104.25(2.98)$ & $106.68(2.81)$ & $105.66(2.78)$ & $105.53(2.90)$ \\
\hline & iii. Packing material & $75.15(2.15)$ & $77.20(2.03)$ & $76.56(2.01)$ & $76.30(2.10)$ \\
\hline & iv. Loading and unloading charges & $14.16(0.40)$ & $16.56(0.44)$ & $15.34(0.40)$ & $15.35(0.42)$ \\
\hline & v. Transportation charges & $35.40(1.01)$ & $37.60(0.99)$ & $36.40(0.96)$ & $36.46(1.00)$ \\
\hline & Sub-total (2-I to V) & $263.68(7.53)$ & $274.90(7.23)$ & $269.40(7.09)$ & $269.31(7.41)$ \\
\hline 3 & Net margins of pre-harvest contractor & $276.32(7.89)$ & $365.10(9.61)$ & $330.60(8.70)$ & $310.69(8.55)$ \\
\hline 4 & $\begin{array}{l}\text { Sale price of pre-harvest contractor/purchase price of } \\
\text { wholesaler }\end{array}$ & $1350(38.57)$ & $1460(38.42)$ & $1400(36.84)$ & $1390(38.26)$ \\
\hline 5 & Cost incurred by the wholesaler & & & & \\
\hline & i. Loading, unloading and transportation charges & $13.28(0.38)$ & $14.46(0.38)$ & $13.88(0.37)$ & $13.87(0.38)$ \\
\hline & ii. Grading and repacking charges & $74.16(2.12)$ & $75.14(1.98)$ & $74.88(1.97)$ & $74.72(2.06)$ \\
\hline & iii. Commission@6 percent & $81.00(2.31)$ & $87.00(2.29)$ & $84.00(2.21)$ & $83.40(2.30)$ \\
\hline & iv. Market free@3 percent & $40.50(1.16)$ & $43.50(1.14)$ & $42.00(1.11)$ & $41.70(1.15)$ \\
\hline & v. Spoilage and storage charge & $58.40(1.67)$ & $59.60(1.57)$ & $58.88(1.55)$ & $58.96(1.62)$ \\
\hline & Sub total (5-I to V) & $267.34(7.64)$ & $279.70(7.36)$ & $273.64(7.20)$ & $272.65(7.50)$ \\
\hline 6 & Net margin of wholesaler & $232.66(6.65)$ & $220.30(5.80)$ & $246.36(6.48)$ & $240.35(6.62)$ \\
\hline 7 & Sale price of wholesaler/purchase price of retailer & $1850(52.86)$ & $1960(51.58)$ & $1920(50.53)$ & 1903(52.38) \\
\hline 8 & Cost incurred by the retailer & & & & \\
\hline & i. Transportation charges & $25.30(0.72)$ & $26.12(0.69)$ & $25.88(0.68)$ & $25.77(0.71)$ \\
\hline & ii. Loading and unloading charges & $17.05(0.49)$ & $19.12(0.50)$ & $18.66(0.49)$ & $18.28(0.50)$ \\
\hline & iii. Spoilage & $31.42(0.90)$ & $32.44(0.85)$ & $31.88(0.84)$ & $31.91(0.88)$ \\
\hline & iv. Packing material(Tockry and Petti & $29.54(0.84)$ & $30.73(0.81)$ & $29.92(0.79)$ & $30.06(0.83)$ \\
\hline & v. Other charges (rent of cart or shop etc. & $29.45(0.84)$ & $30.56(0.80)$ & $30.00(0.79)$ & $30.00(0.83)$ \\
\hline & Sub total (8-I to V) & $132.76(3.79)$ & $138.97(3.66)$ & $136.34(3.59)$ & $136.02(3.74)$ \\
\hline 9 & Net margin of retailer & $1517.24(43.35)$ & $1701.03(44.76)$ & $1743.66(45.89)$ & $1593.98(43.88)$ \\
\hline $\begin{array}{l}1 \\
0\end{array}$ & Sale price of retailer/purchase price of consumer & $3500(100.00)$ & $3800(100.00)$ & $3800(100.00)$ & $3633.00(100.00)$ \\
\hline
\end{tabular}

Note : Figures in parentheses are the percentage to the consumer's price

Consumer

Marketing Channel I: Producer $\rightarrow$ Pre-Harvester Contractor $\rightarrow$ Commission agent $\rightarrow$ Wholesaler $\rightarrow$ Retailer $\rightarrow$

Table 2: Price spread of guava in channel-II in Hisar, Fatehabad, Sirsa market and Overall average ( $/$ qtls)

\begin{tabular}{|c|c|c|c|c|c|}
\hline $\begin{array}{l}\text { Sr. } \\
\text { No }\end{array}$ & Particulars & Hisar & Fatehabad & Sirsa & Overall average \\
\hline 1 & $\begin{array}{l}\text { Net Price received by producer/purchase } \\
\text { Price of pre-harvest contractor }\end{array}$ & $810(25.31)$ & $820(24.12)$ & $800.00(22.86)$ & $810(24.18)$ \\
\hline \multirow[t]{7}{*}{2} & Cost incurred by the pre-harvest contractor & & & & \\
\hline & i. Watch and Ward & $34.72(1.09)$ & $36.86(1.08)$ & $35.44(1.01)$ & $35.67(1.06)$ \\
\hline & ii. Picking, grading and packing cost & $104.25(3.26)$ & $106.68(3.14)$ & $105.66(3.02)$ & $105.53(3.15)$ \\
\hline & iii. Packing material & $75.15(2.35)$ & $77.20(2.27)$ & $76.56(2.19)$ & $76.30(2.28)$ \\
\hline & iv. Loading and unloading charges & $35.40(1.11)$ & $16.56(0.49)$ & $15.34(0.44)$ & $15.35(0.46)$ \\
\hline & v. Transportation charges & $14.16(0.44)$ & $37.60(1.11)$ & $36.40(1.04)$ & $36.46(1.09)$ \\
\hline & Sub-total (2-I to V) & $263.68(8.24)$ & $274.90(8.09)$ & $269.40(7.70)$ & $269.31(8.04)$ \\
\hline 3 & Net margins of pre-harvest contractor & $186.32(5.82)$ & $405.10(11.91)$ & $290.60(8.30)$ & $320.69(9.57)$ \\
\hline 4 & $\begin{array}{l}\text { Sale price of pre-harvest contractor/ } \\
\text { purchase price of retailer }\end{array}$ & $1260(39.38)$ & $1500.00(44.12)$ & $1360.00(38.86)$ & $1400.00(41.79)$ \\
\hline \multirow[t]{9}{*}{5} & Cost incurred by the retailer & & & & \\
\hline & i. Transportation charges & $25.30(0.79)$ & $26.12(0.77)$ & $25.88(0.74)$ & $25.77(0.77)$ \\
\hline & ii. Loading and unloading charges & $17.05(0.53)$ & $19.12(0.56)$ & $18.66(0.53)$ & $18.28(0.55)$ \\
\hline & iii. Commission@6 percent & $78.60(2.46)$ & $90.00(2.65)$ & $81.60(2.33)$ & $84.00(2.51)$ \\
\hline & iv. Market free@3 percent & $37.80(1.18)$ & $45.00(1.32)$ & $40.80(1.17)$ & $42.00(1.25)$ \\
\hline & v. Spoilage & $31.42(0.98)$ & $32.44(0.95)$ & $31.88(0.91)$ & $31.91(0.95)$ \\
\hline & vi. Packing material (polythene bag) & $29.54(0.92)$ & $30.73(0.90)$ & $29.92(0.85)$ & $30.06(0.90)$ \\
\hline & vii. Other charges (rent of cart or shop etc) & $29.45(0.92)$ & $30.50(0.90)$ & $30.00(0.86)$ & $30.00(0.90)$ \\
\hline & Sub total (5-I to vii) & $246.16(7.69)$ & $273.97(8.06)$ & $258.74(7.39)$ & $262.02(7.82)$ \\
\hline 6 & Net margin of retailer & $1693.84(52.93)$ & $1626.03(47.82)$ & $1881.26(53.75)$ & $1687.98(50.39)$ \\
\hline 7 & Sale price of retailer /Purchase price of consumer & $3200(100.00)$ & $3400.00(100.00)$ & $3500.00(100.00)$ & $3350.00(100.00)$ \\
\hline
\end{tabular}


Marketing Channel II: Producer $\rightarrow$ Pre Harvester Contractor $\rightarrow$ Commission agent $\rightarrow$ Wholesaler $\rightarrow$ Retailer $\rightarrow$ Consumer

Table 3: Price spread of guava in channel-III in Hisar, Fatehabad, Sirsa market and Overall average ( $/$ qtls)

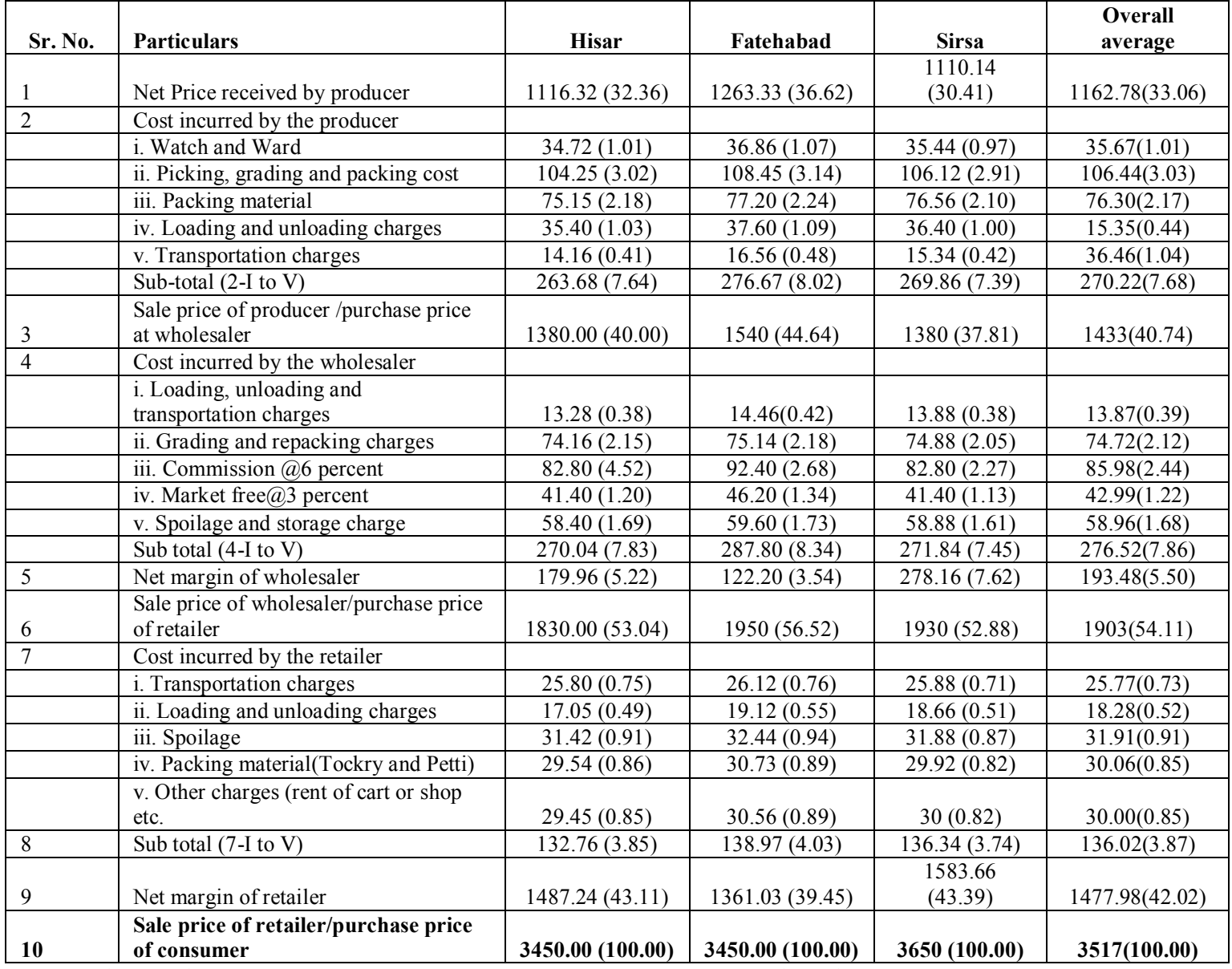

Note: Figures in parentheses are the percentage to the consumer's price

Marketing Channel III: Producer $\rightarrow$ Commission agent $\rightarrow$ Wholeseller $\rightarrow$ Retailer $\rightarrow$ Consumer

Table 4: Price spread of guava in marketing channel -IV in Hisar, Fatehabad, Sirsa market and Overall average

(/ qutls)

\begin{tabular}{|c|c|c|c|c|c|}
\hline $\begin{array}{l}\text { Sr. } \\
\text { No. }\end{array}$ & Particulars & Hisar & Fatehabad & Sirsa & Overall average \\
\hline 1 & Net Price received by producer & $1086.32(33.95)$ & $1323.33(36.76)$ & $1580.14(41.58)$ & $1329.78(37.64)$ \\
\hline \multirow[t]{7}{*}{2} & Cost incurred by the producer & & & & \\
\hline & i. Watch and Ward & $34.72(1.09)$ & $36.86(1.02)$ & $35.44(0.93)$ & $35.67(1.01)$ \\
\hline & ii. Picking, grading and packing cost & $104.25(3.26)$ & $108.45(3.01)$ & $106.12(2.79)$ & $106.44(3.01)$ \\
\hline & iii. Packing material & $75.15(2.35)$ & $77.20(2.14)$ & $76.56(2.01)$ & $76.30(2.16)$ \\
\hline & iv. Loading and unloading charges & $14.16(0.44)$ & $37.60(1.04)$ & $15.34(0.40)$ & $15.35(0.43)$ \\
\hline & & $35.40(1.11)$ & $16.56(0.46)$ & $36.40(0.96)$ & $36.46(1.03)$ \\
\hline & Sub-total (2-I to V) & $263.68(8.24)$ & $276.67(7.69)$ & $269.86(7.10)$ & $270.22(7.65)$ \\
\hline 3 & Sale price of producer/purchase price at retailer & $1350(42.19)$ & $1600(44.44)$ & $1850(48.68)$ & $1600(45.29)$ \\
\hline \multirow[t]{8}{*}{4} & Cost incurred by the retailer & & & & \\
\hline & i. Transportation charges & $25.30(0.79)$ & $26.12(0.73)$ & $25.88(0.68)$ & $25.77(0.73)$ \\
\hline & ii. Loading and unloading charges & $17.05(0.53)$ & $19.12(0.53)$ & $18.66(0.49)$ & $18.28(0.52)$ \\
\hline & iii. Commission@6 percent & $81.00(2.53)$ & $96.00(2.67)$ & $111(2.92)$ & $96.00(2.72)$ \\
\hline & iv. Market free@3 percent & $40.50(1.27)$ & $48.00(1.33)$ & $55.50(1.46)$ & $48.00(1.36)$ \\
\hline & v. Spoilage & $31.42(0.98)$ & $32.44(0.90)$ & $31.88(0.84)$ & $31.91(0.90)$ \\
\hline & vi. Packing material(Tockry and Petti) & $29.54(0.92)$ & $30.73(0.85)$ & $29.92(0.79)$ & $30.06(0.85)$ \\
\hline & vii. Other charges (rent of cart or shop etc. & $29.45(0.92)$ & $30.56(0.85)$ & $30(0.79)$ & $30.00(0.85)$ \\
\hline 5 & Sub total (4-I to V) & $254.26(7.95)$ & $552.97(15.36)$ & $302.84(7.97)$ & $280.02(7.93)$ \\
\hline 6 & Net margin of retailer & $1595.74(49.87)$ & $1447.03(40.20)$ & $1647.16(43.35)$ & $1652.98(46.79)$ \\
\hline 7 & Sale price of retailer/purchase price of consumer & $3200(100.00)$ & $3600(100.00)$ & $3800(100.00)$ & 3533(100.00) \\
\hline
\end{tabular}


Note : Figures in parentheses are the percentage to the consumer's price Marketing Channel IV: Producer $\rightarrow$ Commission agent $\rightarrow$ Retailer $\rightarrow$ Consumer

Table 5: Price spread of guava in channel-IV in Hisar, Fatehabad, Sirsa market and Overall average

(/qtls)

\begin{tabular}{|c|l|c|c|c|c|}
\hline $\begin{array}{c}\text { Sr. } \\
\text { No. }\end{array}$ & \multicolumn{1}{|c|}{ Particulars } & Hisar & Fatehabad & Sirsa & Overall average \\
\hline 1 & Net price received by producer & $2361.03(94.44)$ & $2485.94(95.61)$ & $2408.44(94.45)$ & $2404.89(94.31)$ \\
\hline 2 & Cost incurred by the producer & & & & \\
\hline & i. Watch and ward & $34.72(1.39)$ & $36.86(1.42)$ & $35.44(1.39)$ & $35.67(1.40)$ \\
\hline & ii. Picking cost & $104.25(4.17)$ & $108.45(4.17)$ & $106.12(4.16)$ & $109.44(4.29)$ \\
\hline & Total Cost & $138.97(5.56)$ & $145.31(5.59)$ & $141.56(5.55)$ & $145.11(5.69)$ \\
\hline 3 & Sale price of producer/ purchase price of consumer & $\mathbf{2 5 0 0 ( 1 0 0 . 0 0 )}$ & $\mathbf{2 6 0 0 ( 1 0 0 . 0 0 )}$ & $\mathbf{2 5 5 0 ( 1 0 0 . 0 0 )}$ & $\mathbf{2 5 5 0 ( 1 0 0 . 0 0 )}$ \\
\hline
\end{tabular}

Note : Figures in parentheses are the percentage to the consumer's price Marketing Channel V: Marketing Producer $\rightarrow$ Direct Consumer

Table 6: Overall average marketing efficiency of guava under different marketing channels

\begin{tabular}{|c|c|c|c|c|c|c|c|}
\hline $\begin{array}{l}\text { Sr. } \\
\text { No. }\end{array}$ & Particulars & Units & Channel I & $\begin{array}{c}\text { Channel } \\
\text { II }\end{array}$ & $\begin{array}{c}\text { Channel } \\
\text { III }\end{array}$ & $\begin{array}{c}\text { Channel } \\
\text { IV }\end{array}$ & $\begin{array}{c}\text { Channel } \\
\mathrm{V}\end{array}$ \\
\hline 1 & $\begin{array}{l}\text { Retailers sale price or } \\
\text { consumers purchase price } \\
\text { (RP) }\end{array}$ & Rs./qtls & 3633 & 3350 & 3517 & 3533 & 2550 \\
\hline 2 & Total marketing cost (MC) & Rs./qtls & 677.98 & 531.33 & 682.76 & 550.24 & 145.11 \\
\hline 3 & $\begin{array}{l}\text { Total net margins of } \\
\text { intermediaries }(\mathrm{MM})\end{array}$ & Rs./qtls & 2145.02 & 2008.67 & 1671.46 & 1652.98 & - \\
\hline 4 & $\begin{array}{l}\text { Net price received by } \\
\text { farmers (FP) }\end{array}$ & Rs./qtls & 810 & 810 & 1162.78 & 1329.78 & 2404.89 \\
\hline \multirow[t]{2}{*}{5} & Value added (1-4) & Rs./qtls & 2823 & 2540 & 2354.22 & 2203.22 & 145.11 \\
\hline & $\begin{array}{l}\text { Index of marketing } \\
\text { efficiency }\end{array}$ & & & & & & \\
\hline $\mathrm{A}$ & $\begin{array}{l}\text { Acharyas Method (MME) } \\
4 \div(2+3)\end{array}$ & Ratio & 0.28 & 0.31 & 0.49 & 0.60 & 16.57 \\
\hline $\mathrm{B}$ & Conventional Method $5 \div 2$ & Ratio & 4.16 & 4.78 & 3.45 & 4.00 & 1.00 \\
\hline $\mathrm{C}$ & $\begin{array}{l}\text { Sepherds method (ME) } \\
1 \div 2\end{array}$ & Ratio & 5.36 & 6.30 & 5.15 & 1.60 & 17.57 \\
\hline
\end{tabular}

\section{References}

[1]. Abassian, M., Karim, M, H., Esmaeili, M. and Ebrahimzadeh, H. (2012). The economic analysis of marketing margin of Mazafati date. A case study of Sistan and Blouchestan- Iran. International J. Agril. and crop Sci. IJACS. 4(7): 390-397.

[2]. Acharya, S.S. and Agarwal, N.L. (2011). Market Integration, Efficiency, Costs, Margins and Price Spread. Agril. Mktg. in Ind. pp440-443.

[3]. Anonymous 2010. Haryana Horticulture Database. Directorate of Horticulture, Haryana.

[4]. Kumar, B., Mistry, N.C., Singh, B. and Gandhi, C.P. (2010). Indian Horticulture Database National Horticulture Board, Gurgaon. pp. 79-81.

[5]. Malaisamy, A. ,Chandrasekaran, M. and Parimalarangan, R. (2007). An Economic Analysis of Supply Management Efficiency of Mango in Tamilnadu, India. Ind. J. Agril. Mktg. (Conf. Spl.) 21(3): 125-133.

[6]. Naphade S.A. and Tingre A.S. (2008). Economics of production and marketing of guava in buldhana district of Maharashtra. Ind. J. Agril. Mktg. 22(2): 32-41.

[7]. Nirgude, R.R., Shendage, P.N. and Jadhav, K.L. (2007). Marketing of Sapota in Thane District. Ind. J. Agril. Mktg. 21(2): 171-180.

[8]. Randev, A. K. (2005). Marketing of Apple in Shimla district of Himachal Pradesh-India. Ind. J. Agril. Mktg. 19(3): 11-19.

[9]. Sundaravaradarajan, K.R. and Jaganmohan, K.R. (2002). Marketing cost, margin, price spread and marketing efficiency of cashew in Tamil Nadu. Agric. Situat. India, 59(1): 9-16. 